\title{
The Influence of Marketing Mix, Costumer Value, and Customer Satisfaction on the Purchase Intention of Granite and Marble Natural Stone at PT. Intinusa Selareksa, Tbk, Jakarta
}

\author{
Noviandy Hermanto $^{1}$, Afriapollo Syafarudin ${ }^{2}$, Ahmad Badawi Saluy $^{3}$ \\ \{Noviandy.hermanto@gmail.com ${ }^{1}$, afriapollo88@gmail.com², ahmad.badawi@mercubuana.ac.id ${ }^{3}$ \} \\ Mercu Buana University, Jakarta, Indonesia ${ }^{12}$
}

\begin{abstract}
This study aims to determine Marketing Mix, Customer Value, Customer Satisfaction with the intention to purchase granite and marble natural stone in the company. The research with quantitative descriptive methods conducted in March 2020 for customers of PT. Intinusa Selareka Tbk. The sample used was 100 people and the sampling technique was done by simple random sampling. Data obtained using a questionnaire and processed using Smart PLS 3.0 analysis.
\end{abstract}

Keywords: HRIS Implementation, Motivation, Competence and Employee Performance

\section{Introduction}

Property growth in 2018 was not too encouraging. The unstable national and global economic conditions make investors and consumers refrain from investing in the property sector. Property sales in 2018 for the medium to upper class are very heavy, only subsidized housing will increase significantly. This is because of the condition of Rupiah continues to weaken. All developers and observers acknowledge that the market situation is still heavy despite good economy growth, maintained inflation and low interest rates. So also, it is felt by PT. Intinusa Selareksa, tbk, although challenging condition in 2018, the company achieved sales of 20.1 billion Rupiah or decreased by $1.0 \%$ from the previous year of 20.3 billion Rupiah, but with the company strategy and hard work, it succeeded in increasing the project contracts obtained during 2018 which are still in the completion stage in 2019.

From the picture 1 above illustrated that Currently the demand for granite and marble raw materials for property such as housing is increasing. Where the demand for the product is expected to be influenced by the marketing mix strategy undertaken by the company, which is to achieve marketing objectives in the target market. One effort to satisfy customers is to formulate and compile a combination of policies covering $7 \mathrm{P}[1]$. 


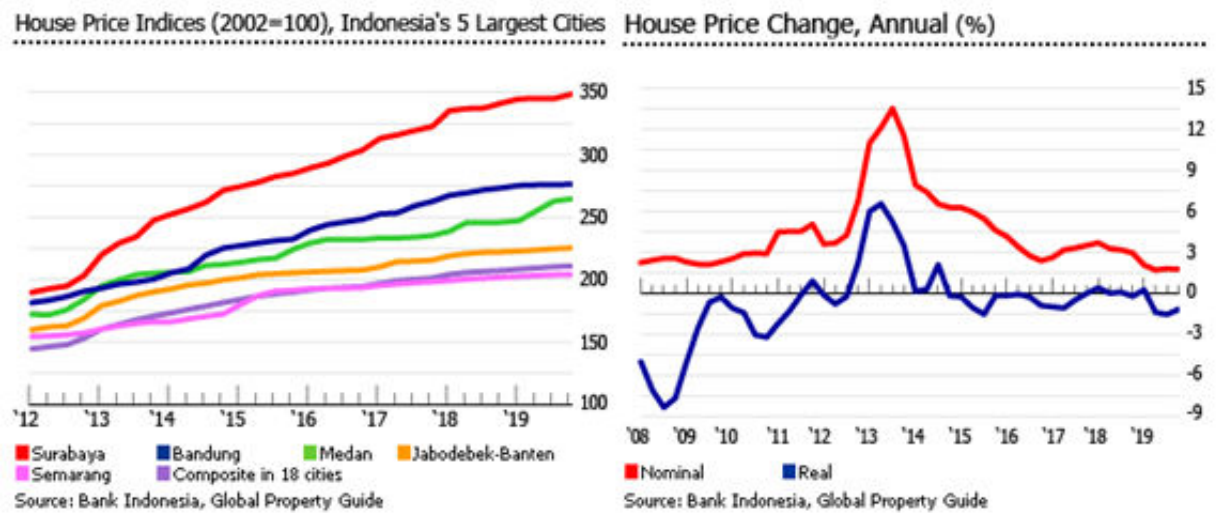

Fig 1. House Price

\subsection{Literature Review \\ 1.1.1 Marketing Definition}

According to Canon et al [2], marketing is an activity aimed at achieving company goals, carried out by anticipating customer needs and directing the flow of goods and services that meet the needs of customers or clients of the manufacturer. According to Laksana [3], marketing is any activity that offers a product to meet the needs and desires of consumers. According to Kotler and Keller [1], that marketing is a social process where individuals and groups get what they need and want by creating and exchanging products with individual and other group values.

\subsubsection{Marketing Mix}

Marketing mix means product strategy, distribution, promotion, and pricing to produce, carry out exchanges and reach target markets, where the marketing mix can be considered as interrelated actions and solutions to meet consumer needs and to achieve the company's marketing objectives, as a whole [4]. Pruskus in Isoraite [5] reveals the marketing mix - a set of factors and relevant solutions that enable customers to meet (national) needs and achieve the goals set by the company.

\subsubsection{Customer Value}

Zeithaml [6], Lee, Suh and Lee [7] states that customer value is a general evaluation of product utility by customers based on perceived benefits and costs. Anderson [8], defines customer value as the perceived value of the monetary unit of economic, technological, service and social benefits obtained in the exchange process between the company and the customer regarding the price paid for products and services.

\subsubsection{Customer Satisfaction}

Satisfaction [9], [10], [11], [12], comes from the Latin word "satis" which means good enough or adequate and "facio" means to do or make. According to Oliver [13], customer satisfaction is an evaluation of surprises inherent or inherent in the acquisition of products and / or consumption experience. Tse \& Wilton [14] defines customer satisfaction / dissatisfaction as the customer's response to the evaluation of disconfirmation that is perceived between the initial expectation 
before purchase (or other performance norms) and the actual performance of the product perceived after the use or consumption of the product concerned.

\subsubsection{Purchase Intention}

Intention to buy is often used to analyze consumer behavior. Before making a purchase, consumers will usually collect information about the product based on personal experience and information from their environment. After the information is collected, the consumer will begin to evaluate the product, conduct an evaluation and make a purchasing decision after comparing the product and considering it [15], [16], [17], [18].

\subsection{Framework}

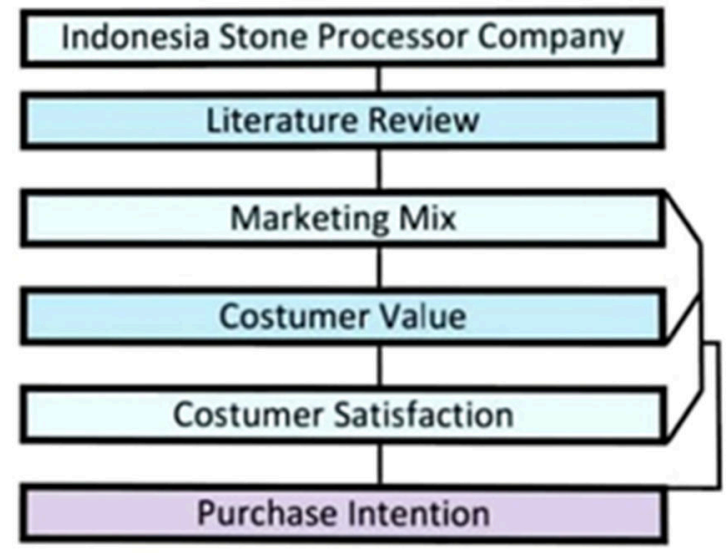

Fig 2. Framework

\section{Research Method}

Data collection in this study was carried out as follows, direct interviews and filling out questionnaires by consumers who have purchased granite and marble natural stone at the company PT. Intinusa Selareka Tbk Jakarta, documenting literature or related data owned by the company, through the internet media to search various sources related to research topics. Research measuring instruments used in the form of questionnaires or questionnaires. Questionnaire is an investigation of a problem that concerns a lot of public interest, by circulating questionnaire forms, submitted in writing to a number of objects, to get answers in the form of responses and written responses as needed [19].

The questionnaire is a very practical data collection technique, namely by making a list of questions in writing in accordance with the intent or required data that is answered or filled out by respondents and used to collect facts in the form of opinions, desires and so forth. The form of the questionnaire chosen was a multiple-choice form (multiple-choice), where respondents were asked 
to choose one of the many possible answers or alternatives. As for the alternatives such as very agree, agree, less agree, strongly agree, and so on [19]. For the purposes of quantitative analysis, the scores on each variable are given the following scores, strongly Agree score 5, agree score 4, neutral score 3 , disagree score 2 , strongly disagree score 1 .

\section{Results and Discussion}

Questionnaire data results for the Marketing Mix variable were measured through 5 statement items. Based on the calculation results, an overview of the Marketing Mix variable can be seen through the following table.

\begin{tabular}{|c|c|c|c|c|c|c|c|c|c|}
\hline \multirow[b]{2}{*}{ No. } & \multirow[b]{2}{*}{ Questions } & \multicolumn{5}{|c|}{ Respondence Answer } & \multirow{2}{*}{$\begin{array}{l}\text { Total } \\
\text { Score }\end{array}$} & \multirow{2}{*}{$\begin{array}{l}\text { Ideal } \\
\text { Score }\end{array}$} & \multirow[b]{2}{*}{ Percentage } \\
\hline & & \begin{tabular}{|l|}
$\mathrm{SA}$ \\
\end{tabular} & \begin{tabular}{|l|l|}
$\mathrm{A}$ & \\
\end{tabular} & \begin{tabular}{|l|}
$\mathbf{N}$ \\
\end{tabular} & D & $\overline{\text { SD }}$ & & & \\
\hline$\overline{X_{11}}$ & & 41 & 44 & 13 & 2 & 0 & 424 & 500 & $84,80 \%$ \\
\hline$\overline{X_{12}}$ & & 36 & 52 & 8 & 4 & 0 & 420 & 500 & $84,00 \%$ \\
\hline$\overline{X_{13}}$ & & 40 & 45 & 12 & 3 & 0 & 422 & 500 & $84,40 \%$ \\
\hline$\overline{X_{14}}$ & & 30 & \begin{tabular}{|l|}
41 \\
\end{tabular} & 22 & 6 & 1 & 393 & 500 & $78,60 \%$ \\
\hline$\overline{X_{15}}$ & & 42 & 39 & 14 & 3 & 2 & 416 & 500 & $83,20 \%$ \\
\hline & & & & erag & & & & & $83,00 \%$ \\
\hline
\end{tabular}

Based on the table above obtained an average percentage of achievement of the total score of an ideal score of $83.00 \%$. The percentage is then mapped into the continuum line as follows:

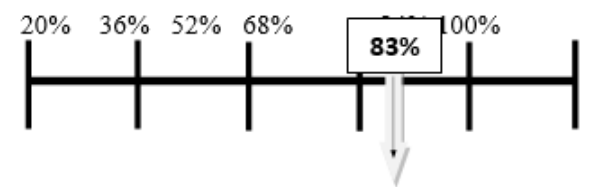

From the responses of 100 respondents and 5 statements, the percentage of total score achieved against the ideal score of $83.00 \%$, where the percentage is in the range of $68 \%$ to $83.99 \%$. Thus, it can be concluded that based on respondents' responses, Marketing Mix is included in the "Good" category. This stage is related to the formation of the initial model of the initial structural equation model, before estimating. This initial model was formulated based on a theory or previous research. Through the conceptual diagram above, it can be seen that the path model consists of 2 (two) sub-structures. In general, the two sub-structures can be described through the following equations:

$$
\begin{gathered}
\mathrm{Z}=\gamma 1 \mathrm{X} 1+\gamma 2 \mathrm{X} 2+\zeta 1 \\
\mathrm{Y}=\gamma 3 \mathrm{X} 1+\gamma 4 \mathrm{X} 2+\beta 1 \mathrm{Z}+\zeta 2
\end{gathered}
$$




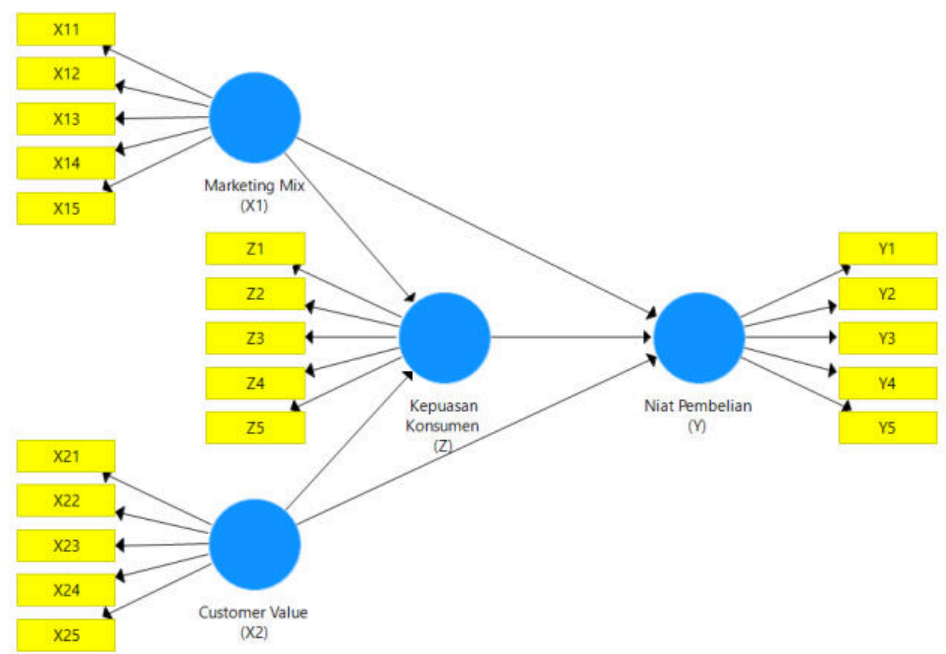

Fig 3. Conceptual Diagram of Partial Least Square

The estimation process of the above models is carried out using the assistance of the SmartPLS 3.0 application program.

\begin{tabular}{|c|c|c|c|c|}
\hline & Costumer Value & Costumer Satisfaction & Marketing Mix & Purchase Intention \\
\hline $\mathrm{X} 11$ & & & 0.762 & \\
\hline $\mathrm{x} 12$ & & & 0.829 & \\
\hline $\mathrm{x} 13$ & & & 0.818 & \\
\hline $\mathrm{x} 14$ & & & 0.754 & \\
\hline $\mathrm{X} 15$ & & & 0.769 & \\
\hline \multicolumn{5}{|l|}{$\mathrm{X} 16$} \\
\hline \multicolumn{5}{|l|}{$\mathrm{X} 17$} \\
\hline \multicolumn{5}{|l|}{$\mathrm{X} 18$} \\
\hline \multicolumn{5}{|l|}{ X19 } \\
\hline \multicolumn{5}{|l|}{ X20 } \\
\hline $\mathrm{X} 21$ & 0.808 & & & \\
\hline$\times 22$ & 0.731 & & & \\
\hline $\mathrm{X} 23$ & 0.874 & & & \\
\hline $\mathrm{X} 24$ & 0.810 & & & \\
\hline X25 & 0.822 & & & \\
\hline $\mathrm{Y} 1$ & & & & 0.737 \\
\hline $\mathrm{Y} 2$ & & & & 0.730 \\
\hline $\mathrm{Y}_{3}$ & & & & 0.817 \\
\hline $\mathrm{Y}_{4}$ & & & & 0.796 \\
\hline $\mathrm{Y5} 5$ & & & & 0.803 \\
\hline $\mathrm{Z1}$ & & 0.753 & & \\
\hline $\mathrm{Z2}$ & & 0.765 & & \\
\hline $\mathrm{Z3}$ & & 0.776 & & \\
\hline $\mathrm{Z4}$ & & 0.774 & & \\
\hline 25 & & 0.738 & & \\
\hline
\end{tabular}


Based on the picture above, it appears that all loading factors have values above 0.50 . Thus, it can be concluded that the construct has a good convergent validity. The value of cross loadings presented through the table above also shows a good discriminant validity, where the correlation value of indicators with their construct is higher than the correlation value of indicators with other constructs [20]. This is indicated by the green color in the coefficient values presented through the SmartPLS application program output table above. The next stage assesses Cronbach's Alpha criteria, Composite Reliability, and Average Variance Extracted (AVE). Each construct is said to be reliable if it has a Cronbach's Alpha and Composite Reliability greater than 0.70 , while the AVE value is expected to be greater than $0.50[20]$.

\begin{tabular}{|l|c|c|c|c|}
\hline & Cronbach's Alpha & rho_A & Composite Rel & Average Varian \\
\hline Costumer Value & 0.868 & 0.873 & 0.905 & 0.657 \\
\hline Costumer Satisfaction & 0.819 & 0.819 & 0.873 & 0.580 \\
\hline Marketing Mix & 0.846 & 0.848 & 0.890 & 0.620 \\
\hline Purchase Intention & 0.836 & 0.838 & 0.884 & 0.605 \\
\hline
\end{tabular}

Fig 4. Cronbach's Alpha Value, Composite Reliability, and Average Variance Extracted (AVE)

\section{Conclusion}

Based on the overall explanation of the analysis of statistical calculations on the analysis of structural models and hypothesis testing, it can be concluded that partially, the Marketing Mix, proved to have a significant effect on the Consumer Satisfaction of granite and marble natural stones at PT. Intinusa Selareka Tbk. Jakarta. Based on statistical calculations on the analysis of structural models and hypothesis testing, it can be concluded that partially, Customer Value is proven to have no significant effect on the Purchase Intention of granite and marble natural stone at PT. Intinusa Selareka Tbk. Jakarta.

\section{References}

[1] P. Kotler and K. L. Keller, "Marketing management (13th ed.)," in Prentice Hall., 2009.

[2] American Marketing Association, "Definition of Marketing," About AMA. 2012.

[3] F. Laksana, Manajemen Pemasaran Pendekatan Praktis. 2008.

[4] M. Išoraite, "MARKETING MIX THEORETICAL ASPECTS," Int. J. Res., 2016, doi: 10.5281 /zenodo.56533.

[5] M. Išoraite, "Entrepreneuship and blog marketing," Entrep. Sustain. Issues, 2015, doi: 10.9770/jesi.2014.2.3(6).

[6] A. Parasuraman, V. A. Zeithaml, and A. Malhotra, "E-S-QUAL a multiple-item scale for assessing electronic service quality,” J. Serv. Res., 2005, doi: 10.1177/1094670504271156.

[7] K. Ryu, H. R. Lee, and W. G. Kim, "The influence of the quality of the physical environment, food, and service on restaurant image, customer perceived value, customer satisfaction, and behavioral intentions," Int. J. Contemp. Hosp. Manag., 2012, doi: 10.1108/09596111211206141.

[8] D. J. Flint, C. P. Blocker, and P. J. Boutin, "Customer value anticipation, customer satisfaction and loyalty: An empirical examination," Ind. Mark. Manag., 2011, doi: 10.1016/j.indmarman.2010.06.034.

[9] P. Williams and E. Naumann, "Customer satisfaction and business performance: A firm-level 
analysis,”J. Serv. Mark., 2011, doi: 10.1108/08876041111107032.

[10] F. Tjiptono and G. Chandra, "Service, Quality \& Satisfaction," in Edisi 4, 2011.

[11] R. B. Vukmir, "Customer satisfaction," International Journal of Health Care Quality Assurance. 2006, doi: 10.1108/09526860610642573.

[12] M. D. Johnson, "Customer Satisfaction," in International Encyclopedia of the Social \& Behavioral Sciences: Second Edition, 2015.

[13] M. A. Oliver, "Consumer neoteny: An evolutionary perspective on childlike behavior in consumer society," Evol. Psychol., vol. 14, no. 3, pp. 1-11, 2016, doi: $10.1177 / 1474704916661825$.

[14] D. K. Tse, F. M. Nicosia, and P. C. Wilton, "Consumer satisfaction as a process," Psychol. Mark., 1990, doi: 10.1002/mar.4220070304.

[15] Y. F. Kuo, C. M. Wu, and W. J. Deng, "The relationships among service quality, perceived value, customer satisfaction, and post-purchase intention in mobile value-added services," Comput. Human Behav., 2009, doi: 10.1016/j.chb.2009.03.003.

[16] A. Alhidari and S. Almeshal, "Determinants of Purchase Intention in Saudi Arabia: A Moderating Role of Gender," Br. J. Econ. Manag. Trade, 2017, doi: 10.9734/bjemt/2017/32793.

[17] Q. Bian and S. Forsythe, "Purchase intention for luxury brands: A cross cultural comparison," J. Bus. Res., 2012, doi: 10.1016/j.jbusres.2011.10.010.

[18] K. A. B. Rani, "The Influence of Price and Perceived Quality toward Repurchase Intention with Customer Satisfaction as Mediating Variable (Case Study of Miniso in Pontianak)," J. Manaj. Updat., 2019.

[19] P. D. Sugiyono, metode penelitian kuantitatif, kualitatif,dan R\&D. 2016.

[20] I. Ghozali, "Aplikasi Analisis Multivariate dengan Program IBM SPSS. Yogyakarta: Universitas Diponegoro,” (Edisi 9). Semarang Badan Penerbit Univ. Diponegoro, 2018. 